\title{
Impacts of the aquaculture on the distribution of dissolved organic matter in the coastal Jeju Island, Korea, revealed by absorption and fluorescence spectroscopy
}

Jeonghyun Kim ( $\nabla$ e927913@gmail.com )

Jeju National University https://orcid.org/0000-0001-6839-5721

Yeseul Kim

Korea Institute of Ocean Science and Technology

\section{Sung Eun Park}

National Institute of Fisheries Science

Tae-Hoon Kim

Chonnam National University

\section{Bong-Guk Kim}

Underwater Survey Technology 21

Dong-Jin Kang

Korea Institute of Ocean Science and Technology

TaeKeun Rho

Korea Institute of Ocean Science and Technology

\section{Research Article}

Keywords: aquaculture, anthropogenic organic pollution, chromophoric dissolved organic matter, fluorescent dissolved organic matter, eutrophication, Jeju Island

Posted Date: February 5th, 2021

DOI: https://doi.org/10.21203/rs.3.rs-183257/v1

License: (c) (1) This work is licensed under a Creative Commons Attribution 4.0 International License. Read Full License

Version of Record: A version of this preprint was published at Environmental Science and Pollution Research on July 31st, 2021. See the published version at https://doi.org/10.1007/s11356-021-15553-3. 


\section{Abstract}

To demonstrate behavior of dissolved organic matter (DOM) derived from coastal aquaculture, dissolved organic carbon (DOC), total dissolved nitrogen (TDN), chromophoric dissolved organic matter (CDOM), and fluorescent dissolved organic matter (FDOM) were measured around the coastal Jeju Island, Korea. As reported by previous studies, pristine groundwater with extremely depleted DOC $(<30 \mu \mathrm{M})$ has been used as culturing water in the coastal aquafarms. However, the concentration of DOC within $1.5 \mathrm{~km}$ from the discharge outlet of the aquafarms was approximately two times higher than that in the groundwater. In addition, the concentration of TDN exponentially increased close to the discharge outlet. These distribution patterns indicate the aquafarm is a significant DOM source. Herein, principal component analysis including the absorption coefficient $\left(a_{350}\right)$, spectral slope coefficient $\left(S_{250-600}\right)$, specific UV absorbance $\left(S U V A_{254}\right)$, and five fluorescent components were applied to categorize DOM origins. We found two distinct groups: aquaculture activity for TDN with high molecular weights and natural biological activity for DOC enrichment. Our study has also critical implications for the efficient monitoring of anthropogenic organic pollutant from aquafarms using unique optical signals.

\section{Introduction}

Global aquaculture industries have grown very fast over the last few decades to provide adequate food resources for the burgeoning population in Asia and the Pacific region (FAO 2018). Concurrently, the accelerated development of the aquaculture industry has resulted in threats to the coastal environment by increasing the discharge of organic waste and inorganic nutrients into coastal aquatic environments. Although many countries have developed environmental standards for sustainable aquaculture operations, improperly managed and overcrowded facilities are still concerned about the trigger of severe pollution (Qin et al. 2005; Strain and Hargrave 2005). In previous studies, the direct excretion and byproduct of microbial metabolic activity in aquafarms contribute highly enriched organic and inorganic substances in drain waters (Brinker et al. 2005; Green et al. 2002; Sindilariu 2007). It has directly provoked negative environmental impacts, such as eutrophication, water quality deterioration, and red tides downstream of the discharge outlet (Rosa et al. 2013).

Dissolved organic matter (DOM) is a complex mixture of various compounds with different molecular structures and chemical compositions through biological processes. In the coastal region, DOM is naturally produced by biological production and subsequent microbial oxidation (Carlson and Hansell 2015) as well as originates from groundwater (Kim and Kim 2017) and rivers (Raymond and Spencer 2015). In addition, anthropogenic organic pollutants can contribute excess DOM contents in the coastal region. The optically sensitive fraction of DOM is characterised by light absorption and fluorescence; these are termed chromophoric- (CDOM) and fluorescent-DOM (FDOM), respectively. Recently, with the development of advanced instruments and techniques, the spectral properties of CDOM and FDOM have been used to determine the behaviours and origins of DOM (Stedmon and Nelson 2015). The detection of absorbance provides ultraviolet (UV) and visible (VIS) absorption spectra, whose properties depend on the concentration and molecular structure of the chromophore in DOM (Stedmon et al. 2000). In addition, a 
series of excitation and emission fluorescence signals across the broad UV-VIS spectra visually show three-dimensional excitation-emission matrix spectroscopies (EEMs). To decipher meaningful information, EEMs have been handled using peak-picking method and statistical principal component analyses (e.g. Parallel Factor Analysis: PARAFAC) (Stedmon and Markager 2005).

To trace aquafarm-driven organic pollutants, the optical properties of organic matter have been investigated in previous studies. Nimptsch et al. (2015) revealed that large amounts of anthropogenic dissolved organic carbon (DOC) with the mostly biodegradable protein-like FDOM derived from landbased aquaculture facilities discharged into the river system in the North Patagonian region. Hambly et al. (2015) identified the origin of organic matter in recirculating aquaculture system (RAS) as the feed, tap water, and processes associated with fish farming and water purification using the EEMs-PARAFAC. Yamin et al. (2017) observed significant accumulation of humic-like organic matter in the culture water during operation of the zero-discharge RAS using the EEMs-PARAFAC. Wang et al. (2020) reported the effects of aquaculture activities on the biogeochemical aspects of POM in the river system of China based on absorption spectroscopy and fluorescence analysis.

Approximately 360 aquafarms are fully operational in the most coastal area of Jeju Island. Even this island is on the branch of the oligotrophic Kuroshio Current, the macroalgal blooms, green tide, have occurred significantly and eventually led to environmental and economic damage. In addition, the aquafarm-driven eutrophication and green tides have been reported worldwide and are getting larger and more frequent (Zhang et al. 2019). Therefore, the characteristics and influence of aquafarm originorganic matter need to be evaluated. The purpose of this study was to determine the distribution patterns of anthropogenic DOM from aquafarms to the pristine coastal Jeju Island and characterise the behaviour of DOM with carbon and nitrogen contents using multi-optical properties, for example, absorption and fluorescence indicators.

\section{Materials And Methods \\ 2.1 Study region}

Jeju Island is a dormant volcanic island in the southern sea of Korea (Fig. 1), which is in the branch of the oligotrophic Kuroshio Current. Due to the porous basalt bedrock, most of the rainwater quickly permeates and is transferred to the coastal ocean through groundwater. Thus, approximately 1,000 artesian springs and wells are located along the coast. This groundwater has been used in approximately $90 \%$ of the freshwater resources for human activities as well as for aquaculture operations. Owing to its consistent hydrological properties ( 7.2 for $\mathrm{pH}$ and 20.0 for salinity) throughout the year, coastal groundwater is used to raise Halibut and Abalone in coastal aquafarms. Approximately 360 aquafarms in the coastal area of Jeju Island are fully operational.

\subsection{Sampling campaigns}


We conducted sampling campaigns near three major coastal aquafarms and one normal coastal region, designated as the control group during 2018 (Fig. 1). The drainage samples were obtained close to the discharge outlet (within $1 \mathrm{~m}$ ) in the aquafarm regions. The coastal water samples near the aquafarms were taken within $1.5 \mathrm{~km}$ from the outlet (Fig. 1) and sampling was performed on sit-in-kayaks because of very shallow depth (avg. 2 m). Water sampling was conducted using an acid-clean Nalgene HDPE plastic beaker.

\subsection{Analysis of hydrological properties}

Temperature and salinity were detected using a portable CastAway-CTD sensor (YSI Inc., OH, USA). The $\mathrm{pH}$ values were measured using a portable probe (YSI Pro1030). These sensors were calibrated using a standard solution before each sampling campaign.

\subsection{Analysis of DOC and total dissolved nitrogen (TDN)}

Samples for DOC and TDN were vacuum filtered through pre-combusted Whatman glass fibre filters. To prevent microbial degradation, the filtrate was acidified using $6 \mathrm{M}$ hydrochloric acid and kept in precombusted $\left(500^{\circ} \mathrm{C}\right.$ for $4 \mathrm{~h}$ ) EPA glass amber vials (Fisher Scientific, NH, USA). The DOC concentration was measured via high-temperature catalytic oxidation using a (TOC) analyser (TOC-L, Shimadzu, Japan). The TDN was analysed simultaneously with DOC using the same TOC analyser equipped with a total nitrogen unit (TNM-L). To analyse this with high accuracy, the system blank was reduced until the signal from the DOC-free distilled water was consistent within the limit of detection $(<5 \mu \mathrm{M}$ for $\mathrm{DOC},<$ $4 \mu \mathrm{M}$ for TDN). The accuracy of the DOC and TDN concentrations was verified with every sample run using deep-sea references (DSR: 41-44 $\mu \mathrm{M}$ for DOC and 30.50-32.50 for TDN, University of Miami). Our DSR measurement results were in good agreement with the consensus values (within $2 \%$ ).

\subsection{Analysis of CDOM and FDOM}

Large particles suspended in water samples were vacuum filtered through pre-combusted Whatman glass fibre filters $\left(500^{\circ} \mathrm{C}\right.$ for $4 \mathrm{~h}$; pore size: $0.7 \mu \mathrm{m}$ ). The filtrate was re-filtered through pre-rinsed $0.2 \mu \mathrm{m}$ polycarbonate filters (Whatman Nuclepore ${ }^{\mathrm{TM}}$ Track-Etched Membranes, USA) to remove bacterial cells and stored in pre-combusted EPA amber glass vials (Fisher Scientific, PA, USA) in a refrigerator below $4{ }^{\circ} \mathrm{C}$.

UV-VIS absorbance spectra and three-dimensional fluorescence excitation-emission matrices (EEMs) were measured simultaneously using a spectrofluorometer (Aqualog, HORIBA Jobin Yvon, NJ, USA). CDOM absorbance was blank-corrected and a baseline correction was applied at $600 \mathrm{~nm}$, assuming negligible CDOM absorption at that wavelength. CDOM absorbance was further converted into Napierian absorption coefficient $[\operatorname{aCDOM}(\lambda)]$, obtained from the following equation:

$$
a_{C D O M}(\lambda)=\frac{2.303 \times A(\lambda)}{L}
$$


where $A(\lambda)$ is the absorbance at a specific wavelength $\left(\mathrm{m}^{-1}\right)$ and $L$ is the cuvette path length in metres. The term $a_{C D O M}(\lambda)$ is generally adopted as a proxy to assess the CDOM content in a water sample. The spectral slope coefficient for the interval of $250-600 \mathrm{~nm}\left(S_{250-600,} \mathrm{~nm}^{-1}\right)$ was derived from the CDOM absorption spectra by fitting the absorption spectra to an exponential decay equation:

$$
a_{\lambda}=a_{\lambda_{r e f}} e^{-S\left(\lambda-\lambda_{r e f}\right)}
$$

where $a$ is the Napierian absorption coefficient $\left(\mathrm{m}^{-1}\right), \lambda$ is the wavelength $(\mathrm{nm})$, and $\lambda_{\text {ref }}$ is the reference wavelength (nm). Specific UV absorbance $\left(S U V A_{254}\right.$ unit: $\left.\mathrm{L} \mathrm{mgC}^{-1} \mathrm{~m}^{-1}\right)$ was derived from the UV absorbance at $254 \mathrm{~nm}$ normalised to the concentration of DOC.

The analysis was performed using scanning emission wavelengths of $249.1-599.2 \mathrm{~nm}$ in $4.5-\mathrm{nm}$ increments and excitation wavelengths of $251-600 \mathrm{~nm}$ in 3-nm increments with an integration time of 5 $s$ (Kim et al. 2020). Rayleigh and Raman scattering peaks of the EEMs were replaced with missing values. The inner filter effect was further corrected with the UV absorbance values of each sample using the Aqualog Software. The non-negativity constraint was applied in all three modes. PARAFAC modelling of 423 EEMs data was performed using the Solo+MIA software package (Eigenvector Research Inc., WA, USA) and two data points were removed as outliers. A core consistency test was applied to validate the model and identify the appropriate number of PARAFAC components (Bro and Kiers 2003). The fluorescence intensities of the samples were normalised every day to the area under the Raman peak of Milli-Q water at an excitation wavelength of $350 \mathrm{~nm}$; these values were expressed as Raman Units (R.U.) (Lawaetz and Stedmon 2009).

\subsection{Statistical analysis}

For the comparison between variables, analysis of variance (ANOVA) was conducted using Microsoft Excel 2016 (Microsoft, WA, USA). The reported values of the measurement are shown as the average and standard deviation values using Microsoft Excel 2016. The smooth trends of each parameter with distance from the discharge outlet were plotted based on the Loess function using the ggplot2 package (version 3.2.1) for R and RStudio (version 1.2.5033, MA, USA).

\section{Results}

\subsection{Hydrological properties in the coastal Jeju Island}

The water temperature in the coastal water showed the typical trend of monsoon regions $\left(24.19 \pm 2.36^{\circ} \mathrm{C}\right.$ in July and August $2018,16.01 \pm 0.47^{\circ} \mathrm{C}$ in April 2018); however, salinity and pH showed no seasonal pattern. The salinity and $\mathrm{pH}$ values were statistically distinct between the drainage, the near-coastal water from the aquafarm outlet, and the normal coastal water as the control site: $32.03 \pm 3.67$ and $7.96 \pm$ 
0.20 at the drainage, $33.16 \pm 0.98,8.16 \pm 0.11$ near the aquafarm outlet, and $33.67 \pm 0.69$ and $8.23 \pm 0.05$ for control site (ANOVA, $p<0.005$, Figure $S 1$ ).

\subsection{DOC and TDN}

The concentrations of DOC were similar in the three different sample groups: $79 \pm 13 \mu \mathrm{M}$ in the control site, $82 \pm 17 \mu \mathrm{M}$ in the drainage, and $83 \pm 14 \mu \mathrm{M}$ in the near-coastal water from the aquafarm outlet (ANOVA, $p=0.58$ ) (Fig. 2(a)). However, the DOC concentration of the drainage samples was approximately three times higher than that of the pristine groundwater on Jeju Island. The DOC concentration in the coastal groundwater was previously reported to be extremely depleted $(26 \pm 11 \mu \mathrm{M}$ in Kim andKim (2017), 21-56 $\mu \mathrm{M}$ in Kim et al. (2013)). Moreover, these concentrations are significantly lower than those in the deep northern Pacific Ocean (33.8 $\pm 0.4 \mu \mathrm{M}$ in Hansell andCarlson (1998)). The concentrations of TDN were considerably higher in the drainage samples $(52.99 \pm 33.00 \mu \mathrm{M})$ than the control site $(8.55 \pm 3.68 \mu \mathrm{M})$ and the near-coastal water from the aquafarm outlet $(17.64 \pm 18.42 \mu \mathrm{M})$ (ANOVA, $p<0.001$ ) (Fig. 2(b)). The TDN concentration in the control site was similar to the endmember values in the inner $(8.3 \mu \mathrm{M})$ and middle $(11.8 \mu \mathrm{M})$ parts of Kahana Bay, Hawaii (Garrison et al. 2003).

\subsection{Characteristics of CDOM}

The coefficients of CDOM $a_{350}$ was higher in the drainage samples $\left(0.47 \pm 0.21 \mathrm{~m}^{-1}\right)$ than the control site $\left(0.32 \pm 0.13 \mathrm{~m}^{-1}\right)$ and the near-coastal water from the aquafarm outlet $\left(0.32 \pm 0.16 \mathrm{~m}^{-1}\right)$ (ANOVA, $\mathrm{p}<$ 0.001 ) (Fig. 2(c)). The $S_{250-600}$ for the drainage samples was $0.018 \pm 0.004 \mathrm{~nm}^{-1}$, increasing to $0.022 \pm$ $0.004 \mathrm{~nm}^{-1}$ in the coastal waters and $0.021 \pm 0.003 \mathrm{~nm}^{-1}$ in the control site (ANOVA, $p<0.001$ ) (Fig. 2(d)). The SUVA 254 for the drainage samples was higher in the drainage samples $(0.49 \pm 0.25 \mathrm{~L} \mathrm{mg}$ $\left.\mathrm{C}^{-1} \mathrm{~m}^{-1}\right)$ than the control site $\left(0.32 \pm 0.12 \mathrm{~L} \mathrm{mg} \mathrm{C}^{-1} \mathrm{~m}^{-1}\right)$ and the near-coastal water from aquafarm outlet $\left(0.32 \pm 0.16 \mathrm{~L} \mathrm{mg} \mathrm{C}^{-1} \mathrm{~m}^{-1}\right.$ ) (ANOVA, $\mathrm{p}<0.001$ ) (Fig. 2(e)).

\subsection{Characteristics of FDOM}

One to six components were retained for the PARAFAC model (Fig. 3). Five components (C1-C5) were identified by correlation with the fluorescence spectra of components in previous studies from the OpenFluor database with Tucker congruence coefficients exceeding 0.95 (Murphy et al. 2014). For the five-component model, the explained variance was $97.452 \%$ for the data set and the core consistency was $48 \%$. The FDOM components were distinguished by three humic-like (C1, C3, and C4) and two protein-like (C2 and C5) components according to each peak location and the literature (Table 1, Fig. 3). 
Table 1

Optical properties of the fluorescent dissolved organic matter (FDOM) components identified by the parallel factor analysis model from the coastal Jeju Island. Component matches $(>0.95$ Tucker congruence coefficient) were identified in previous studies from the OpenFluor database (Murphy et al. 2014).

\begin{tabular}{|c|c|c|c|c|}
\hline Component & $\begin{array}{l}\text { Max. } \\
\text { wavelength } \\
(\text { Ex/Em, unit: } \\
\text { nm) }\end{array}$ & Description & $\begin{array}{l}\text { Number of } \\
\text { matches }\end{array}$ & Previous studies \\
\hline \multirow[t]{3}{*}{1} & \multirow{3}{*}{$\begin{array}{l}251(320) / \\
394\end{array}$} & UV humic-like & \multirow[t]{3}{*}{33} & $\begin{array}{l}\text { C2 (Hambly et al. } \\
2015)\end{array}$ \\
\hline & & $\begin{array}{l}\text { Wastewater, } \\
\text { anthropogenic }\end{array}$ & & $\begin{array}{l}\text { C1 (Heibati et al. } \\
2017 \text { ) }\end{array}$ \\
\hline & & $\begin{array}{l}\text { Possible microbial } \\
\text { reprocessing }\end{array}$ & & $\begin{array}{l}\text { C3 (Murphy et al. } \\
\text { 2011) }\end{array}$ \\
\hline \multirow[t]{3}{*}{2} & \multirow[t]{3}{*}{$281 / 326$} & $\begin{array}{l}\text { Protein-like, amino acid- } \\
\text { like }\end{array}$ & \multirow[t]{3}{*}{24} & $\begin{array}{l}\text { C5 (Hambly et al. } \\
2015)\end{array}$ \\
\hline & & Ocean productivity & & $\begin{array}{l}\text { C4 (Osburn et al. } \\
2016 \text { ) }\end{array}$ \\
\hline & & & & $\begin{array}{l}\text { C5 (Shutova et al., } \\
2014 \text { ) }\end{array}$ \\
\hline \multirow[t]{3}{*}{3} & \multirow[t]{3}{*}{$\begin{array}{l}251(365) / \\
464\end{array}$} & & \multirow[t]{3}{*}{30} & $\begin{array}{l}\text { C4 (Cohen et al. } \\
\text { 2014) }\end{array}$ \\
\hline & & & & $\begin{array}{l}\text { C2 (Kulkarni et al. } \\
2018 \text { ) }\end{array}$ \\
\hline & & & & $\begin{array}{l}\text { C2 (Shutova et al., } \\
\text { 2014) }\end{array}$ \\
\hline \multirow[t]{3}{*}{4} & \multirow[t]{3}{*}{$296 / 408$} & Marine humic-like & \multirow[t]{3}{*}{5} & $\begin{array}{l}\text { C6 (Walker et al. } \\
\text { 2009) }\end{array}$ \\
\hline & & Microbial production & & $\begin{array}{l}\text { C5 (Kowalczuk et al. } \\
2013 \text { ) }\end{array}$ \\
\hline & & & & $\begin{array}{l}\text { C2 (Wünsch et al. } \\
\text { 2015) }\end{array}$ \\
\hline \multirow[t]{3}{*}{5} & \multirow[t]{3}{*}{257 / 339} & $\begin{array}{l}\text { Protein-like, Tryptophan- } \\
\text { like }\end{array}$ & \multirow[t]{3}{*}{4} & $\begin{array}{l}\text { C3 (Nimptsch et al. } \\
\text { 2015) }\end{array}$ \\
\hline & & Biological production & & $\begin{array}{l}\text { C4 (Dainard et al. } \\
2015 \text { ) }\end{array}$ \\
\hline & & Freshly production & & $\begin{array}{l}\text { C4 (Wünsch et al. } \\
2015 \text { ) }\end{array}$ \\
\hline
\end{tabular}


The C1 $\left(\right.$ Max $\left._{\text {ex/em }}=251(320) / 394 \mathrm{~nm}\right)$ resembled wastewater organic matter and/or microbial-origin organic matter from terrestrial and marine sources (Hambly et al. 2015; Heibati et al. 2017; Murphy et al. 2011; Stedmon and Markager 2005). C2 $\left(\operatorname{Max}_{\mathrm{ex} / \mathrm{em}}=281 / 326 \mathrm{~nm}\right)$ was similar to that of the protein-like component (Hambly et al. 2015; Osburn et al. 2016; Shutova et al. 2014). C3 ( $\mathrm{Max}_{\mathrm{ex} / \mathrm{em}}=$ $251(365) / 464 \mathrm{~nm}$ ) corresponds to $\mathrm{FDOM}_{\mathrm{H}}$, traditionally documented to originate from terrestrial organic matter (Cohen et al. 2014; Kulkarni et al. 2019; Shutova et al. 2014). C4 and C5 have very limited matches from the OpenFluor database. The C4 $\left(\mathrm{Max}_{\mathrm{ex} / \mathrm{em}}=296 / 408 \mathrm{~nm}\right)$ matched components from five models in the OpenFluor database (Kowalczuk et al. 2013; Walker et al. 2009; Wünsch et al. 2015), and the location of the maximum peak was similar to that of the marine humic-like component of the recognised $M$ peak (Coble 2007). However, the shape of $C 4$ was too sharp because the humic component usually has a peak with broad wavelengths. In addition, $\mathrm{C} 5\left(\mathrm{Max}_{\mathrm{ex} / \mathrm{em}}=257 / 339 \mathrm{~nm}\right)$ matched only four models in the OpenFluor database (Dainard et al. 2015; Nimptsch et al. 2015; Wünsch et al. 2015) and its location was similar to that commonly reported as a protein-like component associated with recent biological production.

The fluorescence intensities of $\mathrm{C} 1, \mathrm{C} 3$, and C5 were significantly higher in the drainage samples $(0.707 \pm$ 0.316 R.U., $0.731 \pm 0.400$ R.U., and $0.143 \pm 0.163$ R.U., respectively) than in the control site $(0.365 \pm 0.088$ R.U., $0.377 \pm 0.083$ R.U., and $0.014 \pm 0.022$ R.U., respectively) and near-coastal water from aquafarm outlet (0.392 \pm 0.138 R.U., $0.414 \pm 0.139$ R.U., and $0.039 \pm 0.070$ R.U., respectively) (Figs. $2(f, h, j))$. In contrast, the fluorescence intensities of $\mathrm{C} 2$ and $\mathrm{C} 4$ were significantly lower in the drainage samples $(0.261 \pm 0.141$ R.U. and $0.001 \pm 0.002$ R.U., respectively) than in the control site $(0.302 \pm 0.146$ R.U. and $0.007 \pm 0.008$ R.U., respectively) and near-coastal water from the aquafarm outlet ( $0.354 \pm 0.167$ R.U. and $0.008 \pm 0.013$ R.U., respectively) (Figs. 2(g,i)).

\section{Discussion}

\subsection{Spatial distribution of DOM}

In the coastal region near the coastal aquafarms, the relatively lower values of $\mathrm{pH}$ and salinity compared to the control sites indicate the influence of the fresh groundwater mixture (Figure S1). The origins of DOM with carbon and nitrogen contents were demonstrated by the spatial trends of various CDOM and FDOM parameters within a $1.5-\mathrm{km}$ distance from the outlet.

The average concentration of DOC in the wastewater was similar to the control site (Figs. 2 and 4(a)). Although some data points at the drainage samples showed very high concentrations (up to $135 \mu \mathrm{M}$ ), most measurements were relatively lower than near the coastal sea. On the other hand, relatively higher concentrations of DOC were distributed within 500-1000 m from the discharge outlet (Fig. 4(a)). This pattern did not conform to the results of Nimptsch et al. (2015), who reported a significant increase in DOC concentrations close to the outlet. Herein, the constant level of DOC near the coastal region, perhaps due to the coastal groundwater of Jeju Island is very pristine (Kim and Kim 2017; Kim et al. 2013). The 
DOC concentration in the drainage $(82 \pm 17 \mu \mathrm{M})$ should be elevated relative to the groundwater, derived from the fish farming activity. Contrastingly, the concentrations of TDN exponentially increased when close to the aquafarm outlet (Fig. 4(b)), indicating that the wastewater of the aquafarms contains excess nitrogen sources and contributes significantly to the TDN budget in the coastal region. The primary nitrogen sources from aquacultures seem to be faeces, unconsumed feed, and metabolic by-products in inorganic and organic forms (Wang et al. 2012). In addition, the relatively elevated TDN level of the coastal water near the aquafarms compared to the control samples (Fig. 4(b)) should be attributed to the input of wastewater.

The trends of $a_{350}, S_{250-600}$ and $S U V A_{254}$ showed significant variations (Figs. 4(c,d,e)). The CDOM $a_{350}$ value decreased from the discharge outlet within a 500-m distance and then slightly increased to $1000 \mathrm{~m}$. In the coastal region more than $1000 \mathrm{~m}$ from the outlet, the $a_{350}$ slightly increased, similar to the DOC trend. This trend resembled that of SUVA 254 but showed the reverse pattern of $S_{250-600}$. The $S_{250-600}$ typically shows the reverse relationship with the molecular weight, and then regarded as a proxy for the molecular weight and aromaticity of DOM (Blough and Del Vecchio 2002; Helms et al. 2008; Weishaar et al. 2003). Thus, the aquaculture-driven organic matter contains light-sensitive organic matter with high molecular weight.

The distribution of the FDOM components showed two distinct groups with respect to the general properties of the components: humic-like and protein-like components (Fig. 4). The humic-like components $(\mathrm{C} 1, \mathrm{C} 3$, and $\mathrm{C} 5)$ were very high at the discharge outlet and decreased with the distance from the outlet (Fig. $4(f, h, j))$. Humic-like components were previously found to accumulate in the culture water derived from fish faeces, uneaten feed, and fish blood (Leonard et al. 2002; Nimptsch et al. 2015; Yamin et al. 2017), which may corresponds to our results. In addition, Kowalczuk et al. (2009) reported that the $S_{300-500}$ increased with the change in the optical properties from the domination of humic-like components to protein-like ones. In contrast, protein-like components (C2 and C4) increased with distance, with the highest observed within a 500-1000 m distance (Fig. 4(g.i)). However, Nimptsch et al. (2015) reported that protein-like components decreased significantly with distance from the aquafarm but not humic-like components.

\subsection{Results of principal component analysis (PCA)}

The spatial distribution of DOM seems to be not clear. It is attributed by random aquaculture activities depending on the life cycle of culturing fishes and environmental responses, such as hyperthermal and hypoxic events. PCA was conducted to visualise the distribution behaviour and origins of DOM originating from aquaculture facilities (Fig. 5). The PCA model included the DOC, TDN, $a_{350}, S_{250-600}$, $S_{U V A}{ }_{254}$ and FDOM components (C1-C5). The first and second principal components of PCA (PC1 and PC2) accounted for $48.1 \%$ and $18.8 \%$ of the variance in the dataset, respectively. The variable contributions of $\mathrm{C} 4$ and $\mathrm{C} 5$ were relatively lower than other parameters (Fig. 5), indicating that the two components were weakly associated with other parameters. Since C4 and C5 showed very limited 
matches from the OpenFluor database (Table 1), those components may be rare FDOM components in the natural water.

Loading plots on the PCA results clearly showed two different groups of DOM parameters. Along PC1, the

loadings of TDN, $a_{350}, S U V A_{254}, \mathrm{C} 1$, and C3 were clustered and positive, whereas those of $S_{250-600}$ were negative (Fig. 5). Herein, the scores of the drainage group were mostly positive, whereas those of the control and the near-coastal water from the aquafarm outlet were relatively negative. Therefore, the positive loadings on PC1 were considered as the influence of aquaculture activity. In contrast, DOC and C2 clustered and showed negative loadings along PC2, indicating both parameters are closely related and have a common source. Coupled with the distribution of DOC and TDN with distance, the results of PCA demonstrated that the DOC seems to be freshly produced by the biological activity near the aquafarms, whereas the TDN is linked to aquaculture activity (Fig. 6). This was supported by a previous finding that a significant enhancement of DOC concentrations was mainly associated with an increase in protein-like DOM (Nimptsch et al. 2015).

\section{Conclusions}

The multiple absorption and fluorescence properties showed different behaviours of DOC and TDN between the coastal region near the aquaculture facilities and regular sites. The DOC concentration in the drainage was observed to be three times higher than that in the pristine groundwater due to the aquaculture activity. The enrichment of TDN close to the aquafarm outlet is derived from fish faeces, uneaten feed, and fish blood. The spatial distribution patterns of $a_{350}, S_{250-600}$, and SUVA 254 indicate that the relatively higher aromatic and higher molecular weight DOM discharges from the aquafarms. The high molecular weight organic matter is freshly produced in the coastal water column. Based on the results of PCA, the primary factor $(\mathrm{PC} 1 ; 48.1 \%)$ controlling the distribution of organic matter in this region is the aquaculture activity; the secondary factor (PC2; 18.8\%) is coastal autochthonous production in the water column. The simultaneous positive loadings of TDN with $a_{350}, S U V A_{254}$, and humic-like components, as well as the negative $S_{250-600}$, suggest that the TDN is linked to high molecular weight organic matter. The cluster of DOC and protein-like components along PC2 imply that the DOC is mainly produced by fresh biological activity. Based on the results in this study, the optical properties of organic matter can be used as tracers to determine quantitative and qualitative information of organic pollution from the aquafarms. Because the PCA explained less than $70 \%$ of variables, further studies are necessary to find any other processes contribute the organic matter distribution in Jeju Island, especially groundwater-driven organic matter.

\section{Declarations}

\subsection{Ethics approval and consent to participate}

Not applicable 


\subsection{Consent for publication}

Not applicable

\subsection{Availability of data and materials}

The datasets generated during and/or analysed during the current study are available from the corresponding author on reasonable request.

\subsection{Competing interests}

The authors declare that they have no competing interests. This manuscript contains only original data and is not under consideration for publication elsewhere.

\subsection{Funding}

This study is supported by the National Research Foundation (NRF-2020R1F1A1067862). Sung Eun Park was partially supported by a research grant from the National Institute of Fisheries Science (R2021049).

\subsection{Authors' contributions}

JK and SEP conceived and designed this study. JK and SEP conducted the sampling campaigns and measured the hydrological parameters. JK, YK, DJK and TKR performed the spectroscopic analysis. JK and BGK conducted the statistical data analysis including the PARAFAC model. THK contributed to the chemical measurement of DOC and TDN. All authors discussed the results and commented on the manuscript. JK wrote the manuscript with the contribution from all co-authors.

\subsection{Acknowledgements}

We would like to thank Mr. Hong-Seok Hong and Dong-Hwan Kim in the Jeju Fisheries Research Institute for the assistance with sampling campaigns.

\section{References}

Blough NV, Del Vecchio R (2002): Chromophoric DOM in the coastal environment. In: Hansel DA, Carlson CA (Editors), Biogeochemistry of Marine Dissolved Organic Matter. Academic Press, pp. 509-546

Brinker A, Koppe W, Rösch R (2005): Optimised effluent treatment by stabilised trout faeces. Aquaculture $249,125-144$

Bro R, Kiers HAL (2003): A new efficient method for determining the number of components in PARAFAC models. Journal of Chemometrics 17, 274-286

Carlson CA, Hansell DA (2015): DOM Sources, Sinks, Reactivity, and Budgets. In: Hansell DA, Carlson CA (Editors), Biogeochemistry of Marine Dissolved Organic Matter (Second Edition). Academic Press, Boston, 
pp. $65-126$

Coble PG (2007): Marine Optical Biogeochemistry: The Chemistry of Ocean Color. Chemical Reviews 107, $402-418$

Cohen E, Levy GJ, Borisover M (2014): Fluorescent components of organic matter in wastewater: Efficacy and selectivity of the water treatment. Water Res. 55, 323-334

Dainard PG, Guéguen C, McDonald N, Williams WJ (2015): Photobleaching of fluorescent dissolved organic matter in Beaufort Sea and North Atlantic Subtropical Gyre. Marine Chemistry 177, Part 4, 630637

FAO 2018: The State of World Fisheries and Aquaculture 2018-Meeting the sustainable development goals, Rome, Italy

Garrison GH, Glenn CR, McMurtry GM (2003): Measurement of submarine groundwater discharge in Kahana Bay, O'ahu, Hawai'i. Limnology and Oceanography 48, 920-928

Green JA, Brannon EL, Hardy RW (2002): Effects of dietary phosphorus and lipid levels on utilization and excretion of phosphorus and nitrogen by rainbow trout (Oncorhynchus mykiss). 2. Production-scale study. Aquaculture Nutrition 8, 291-298

Hambly AC, Arvin E, Pedersen LF, Pedersen PB, Seredyńska-Sobecka B, Stedmon CA (2015): Characterising organic matter in recirculating aquaculture systems with fluorescence EEM spectroscopy. Water Res. 83, 112-120

Hansell DA, Carlson CA (1998): Deep-ocean gradients in the concentration of dissolved organic carbon. Nature 395, 263-266

Heibati M, Stedmon CA, Stenroth K, Rauch S, Toljander J, Säve-Söderbergh M, Murphy KR (2017): Assessment of drinking water quality at the tap using fluorescence spectroscopy. Water Res. 125, 1-10

Helms JR, Stubbins A, Ritchie JD, Minor EC, Kieber DJ, Mopper K (2008): Absorption spectral slopes and slope ratios as indicators of molecular weight, source, and photobleaching of chromophoric dissolved organic matter. Limnology and Oceanography 53, 955-969

Kim J, Kim G (2017): Inputs of humic fluorescent dissolved organic matter via submarine groundwater discharge to coastal waters off a volcanic island (Jeju, Korea). Sci. Rep. 7, 7921

Kim J, Kim Y, Kang H-W, Kim SH, Rho T, Kang D-J (2020): Tracing water mass fractions in the deep western Indian Ocean using fluorescent dissolved organic matter. Marine Chemistry 218, 103720

Kim T-H, Kwon E, Kim I, Lee S-A, Kim G (2013): Dissolved organic matter in the subterranean estuary of a volcanic island, Jeju: Importance of dissolved organic nitrogen fluxes to the ocean. Journal of Sea 
Kowalczuk P, Durako MJ, Young H, Kahn AE, Cooper WJ, Gonsior M (2009): Characterization of dissolved organic matter fluorescence in the South Atlantic Bight with use of PARAFAC model: Interannual variability. Marine Chemistry 113, 182-196

Kowalczuk P, Tilstone GH, Zabłocka M, Röttgers R, Thomas R (2013): Composition of dissolved organic matter along an Atlantic Meridional Transect from fluorescence spectroscopy and Parallel Factor Analysis. Marine Chemistry 157, 170-184

Kulkarni H, Mladenov N, Datta S (2019): Effects of acidification on the optical properties of dissolved organic matter from high and low arsenic groundwater and surface water. Science of The Total Environment 653, 1326-1332

Lawaetz AJ, Stedmon CA (2009): Fluorescence intensity calibration using the Raman scatter peak of water. Appl Spectrosc 63, 936-940

Leonard N, Guiraud JP, Gasset E, Cailleres JP, Blancheton JP (2002): Bacteria and nutrients-nitrogen and carbon-in a recirculating system for sea bass production. Aquacultural Engineering 26, 111-127

Murphy KR, Hambly A, Singh S, Henderson RK, Baker A, Stuetz R, Khan SJ (2011): Organic Matter Fluorescence in Municipal Water Recycling Schemes: Toward a Unified PARAFAC Model. Environmental Science \& Technology 45, 2909-2916

Murphy KR, Stedmon CA, Wenig P, Bro R (2014): OpenFluor- an online spectral library of auto-fluorescence by organic compounds in the environment. Analytical Methods 6, 658-661

Nimptsch J, Woelf S, Osorio S, Valenzuela J, Ebersbach P, von Tuempling W, Palma R, Encina F, Figueroa D, Kamjunke N, Graeber D (2015): Tracing dissolved organic matter (DOM) from land-based aquaculture systems in North Patagonian streams. Science of The Total Environment 537, 129-138

Osburn CL, Boyd TJ, Montgomery MT, Bianchi TS, Coffin RB, Paerl HW (2016): Optical Proxies for Terrestrial Dissolved Organic Matter in Estuaries and Coastal Waters. Frontiers in Marine Science 2

Qin G, Liu CCK, Richman NH, Moncur JET (2005): Aquaculture wastewater treatment and reuse by winddriven reverse osmosis membrane technology: a pilot study on Coconut Island, Hawaii. Aquacultural Engineering 32, 365-378

Raymond PA, Spencer RGM (2015): Riverine DOM. In: Hansell DA , Carlson CA (Editors), Biogeochemistry of Marine Dissolved Organic Matter (Second Edition). Academic Press, Boston, pp. 509-533

Rosa RdS, Aguiar ACF, Boëchat IG, Gücker B (2013): Impacts of fish farm pollution on ecosystem structure and function of tropical headwater streams. Environmental Pollution 174, 204-213 
Shutova Y, Baker A, Bridgeman J, Henderson RK (2014): Spectroscopic characterisation of dissolved organic matter changes in drinking water treatment: From PARAFAC analysis to online monitoring wavelengths. Water Res. 54, 159-169

Sindilariu P-D (2007): Reduction in effluent nutrient loads from flow-through facilities for trout production: a review. Aquaculture Research 38, 1005-1036

Stedmon CA, Markager S, Kaas H (2000): Optical Properties and Signatures of Chromophoric Dissolved Organic Matter (CDOM) in Danish Coastal Waters. Estuarine, Coastal and Shelf Science 51, 267-278

Stedmon CA, Markager S (2005): Resolving the variability in dissolved organic matter fluorescence in a temperate estuary and its catchment using PARAFAC analysis. Limnology and Oceanography 50, 686697

Stedmon CA, Nelson NB (2015): The Optical Properties of DOM in the Ocean. In: Hansell DA, Carlson CA (Editors), Biogeochemistry of Marine Dissolved Organic Matter (Second Edition). Academic Press, Boston, pp. 481-508

Strain P, Hargrave B (2005): Salmon aquaculture, nutrient fluxes and ecosystem processes in southwestern New Brunswick, Environmental Effects of Marine Finfish Aquaculture. Springer, pp. 29-57

Walker SA, Amon RMW, Stedmon C, Duan S, Louchouarn P (2009): The use of PARAFAC modeling to trace terrestrial dissolved organic matter and fingerprint water masses in coastal Canadian Arctic surface waters. Journal of Geophysical Research: Biogeosciences 114

Wang H, Wang Y, Zhuang W-E, Chen W, Shi W, Zhu Z, Yang L (2020): Effects of fish culture on particulate organic matter in a reservoir-type river as revealed by absorption spectroscopy and fluorescence EEMPARAFAC. Chemosphere 239, 124734

Wang X, Olsen LM, Reitan KI, Olsen Y (2012): Discharge of nutrient wastes from salmon farms: environmental effects, and potential for integrated multi-trophic aquaculture. Aquaculture Environment Interactions 2, 267-283

Weishaar JL, Aiken GR, Bergamaschi BA, Fram MS, Fujii R, Mopper K (2003): Evaluation of Specific Ultraviolet Absorbance as an Indicator of the Chemical Composition and Reactivity of Dissolved Organic Carbon. Environmental Science \& Technology 37, 4702-4708

Wünsch UJ, Murphy KR, Stedmon CA (2015): Fluorescence Quantum Yields of Natural Organic Matter and Organic Compounds: Implications for the Fluorescence-based Interpretation of Organic Matter Composition. Frontiers in Marine Science 2

Yamin G, Borisover M, Cohen E, van Rijn J (2017): Accumulation of humic-like and proteinaceous dissolved organic matter in zero-discharge aquaculture systems as revealed by fluorescence EEM spectroscopy. Water Res. 108, 412-421

Page 14/18 
Zhang Y, He P, Li H, Li G, Liu J, Jiao F, Zhang J, Huo Y, Shi X, Su R, Ye N, Liu D, Yu R, Wang Z, Zhou M, Jiao $N$ (2019): Ulva prolifera green-tide outbreaks and their environmental impact in the Yellow Sea, China. National Science Review 6, 825-838

\section{Figures}

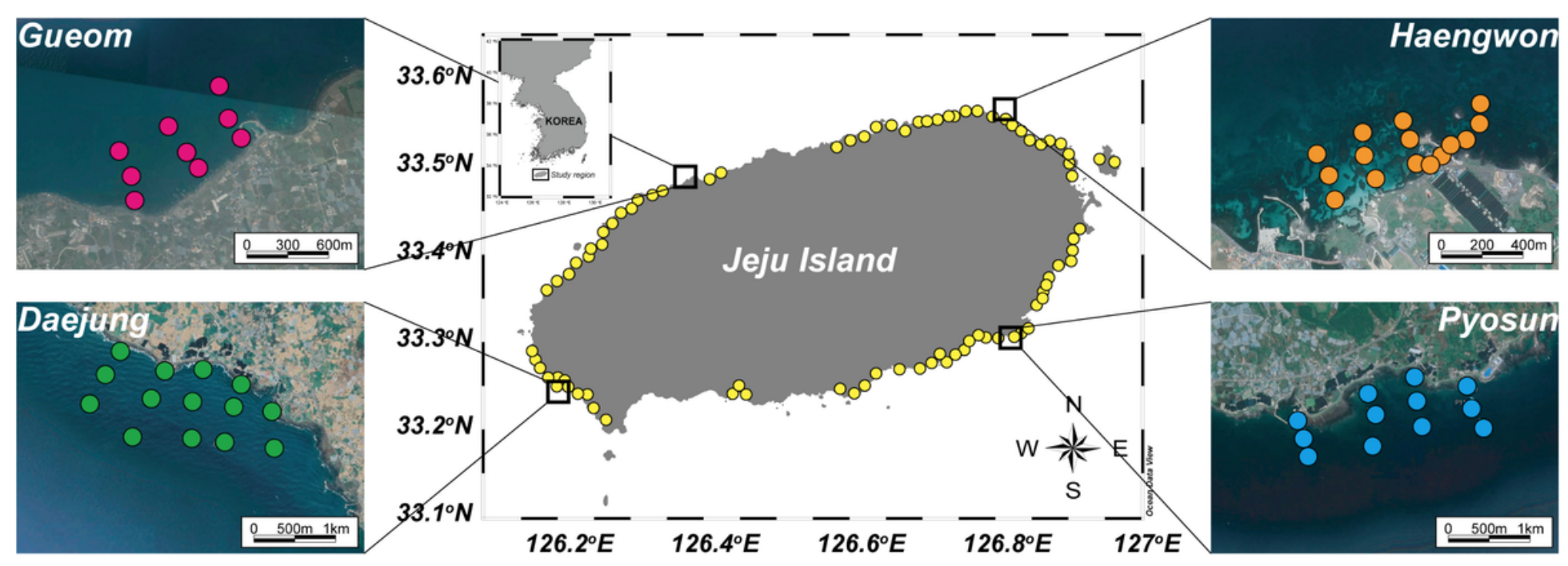

Figure 1

Study region and sampling stations around Jeju Island, Korea. The yellow circles indicate the location of coastal aquafarms. The orange, green, and blue circles were the sampling stations near the aquafarms in area Haengwon, Daejung, and Pyosun districts, respectively. The red circles represent the sampling stations in area Gueom, as the control group, which is located in more than $5 \mathrm{~km}$ distance from the aquafarms.
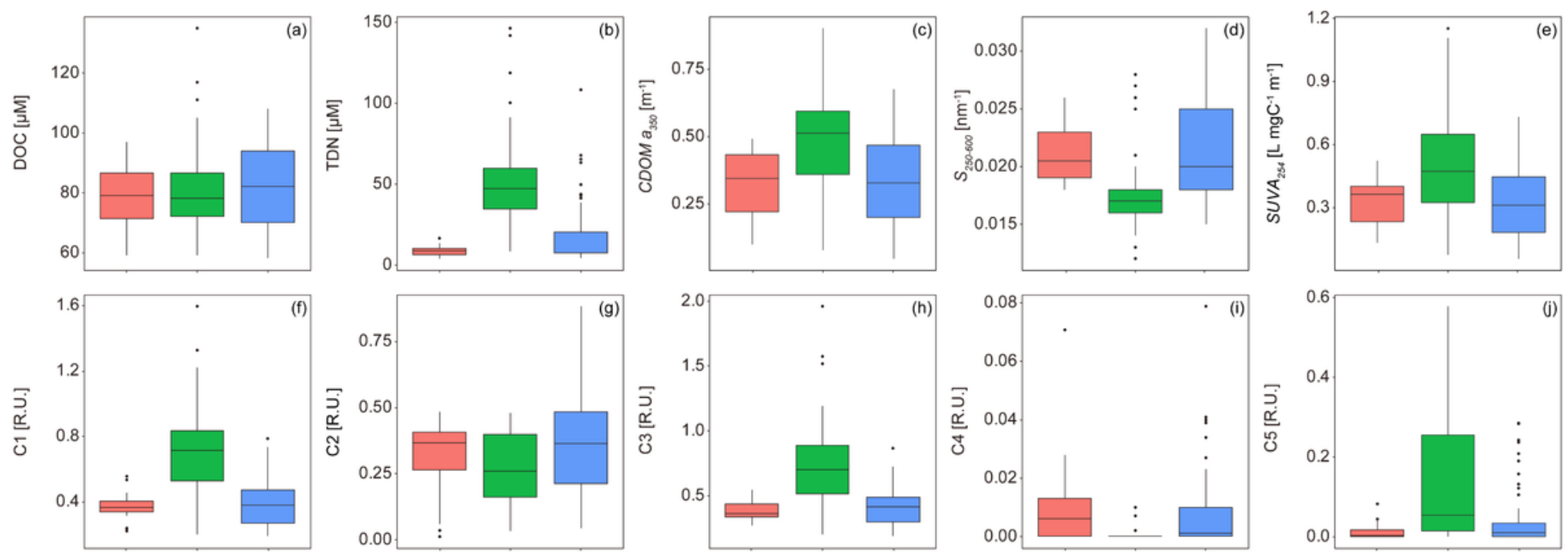

Control Drainage $\pitchfork$ nearAquafarm

Figure 2 
The comparison of the DOC (a), TDN (b), absorption coefficient (c), spectral slope (d), specific UV absorbance (e), and fluorescence intensities of each component $(f-j)$ between the control site (red), the drainage (green), and near-coastal water from the aquafarm outlet (blue)
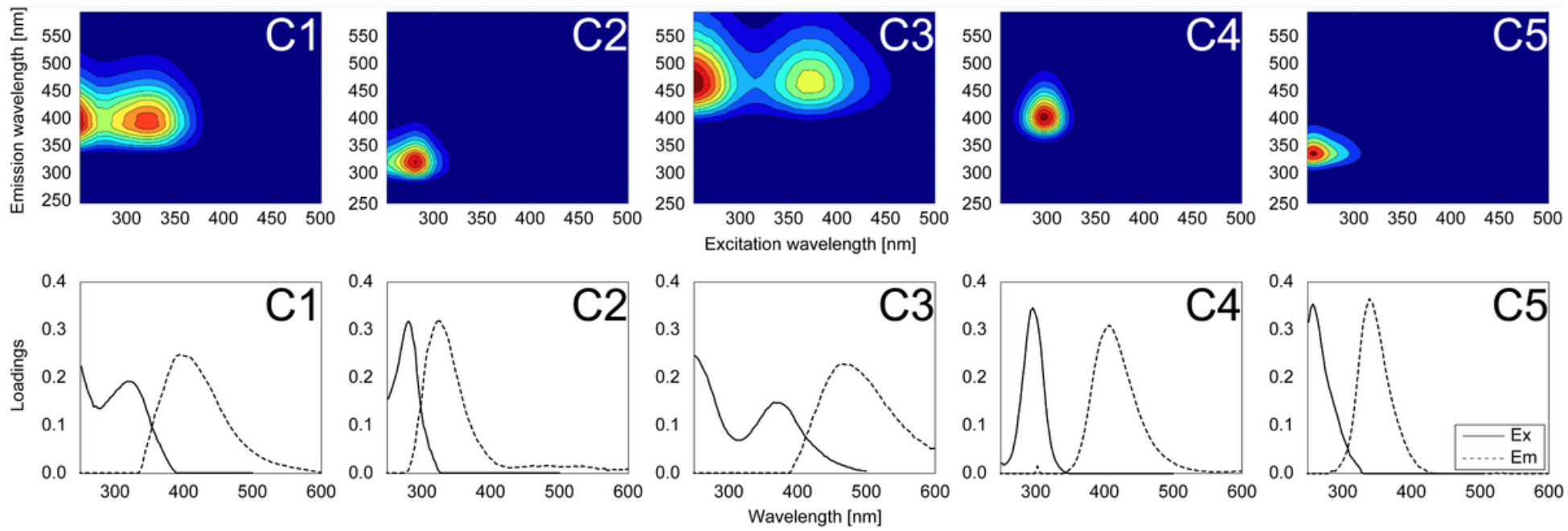

Figure 3

Excitation-emission matrix spectroscopy contour plots (upper row) and loadings (lower row) of five components $(\mathrm{C} 1-\mathrm{C} 5)$ determined by the parallel factor analysis model. The solid and dotted lines represent the excitation and emission wavelengths, respectively.
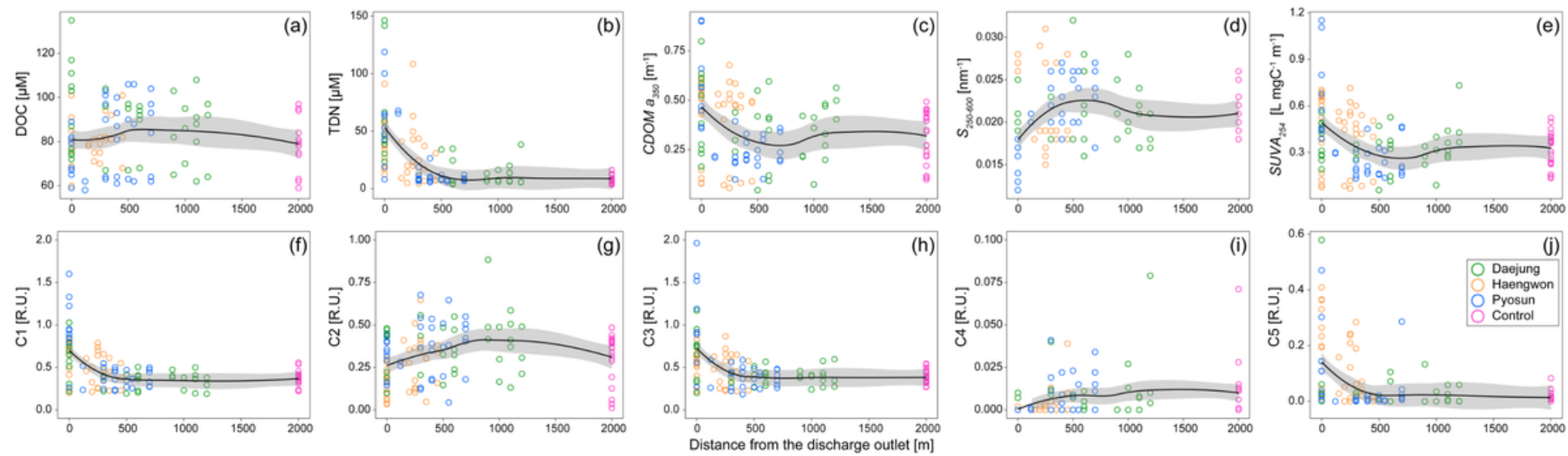

\section{Figure 4}

The DOC (a), TDN (b), absorption coefficient (c), spectral slope (d), specific UV absorbance (e), and fluorescence intensities of each component $(f-j)$ with distance from the aquafarm outlet. The solid lines of each parameter indicate the spatial trend with distance from the discharge outlet based on the Loess function using the ggplot2 package for R and RStudio. 


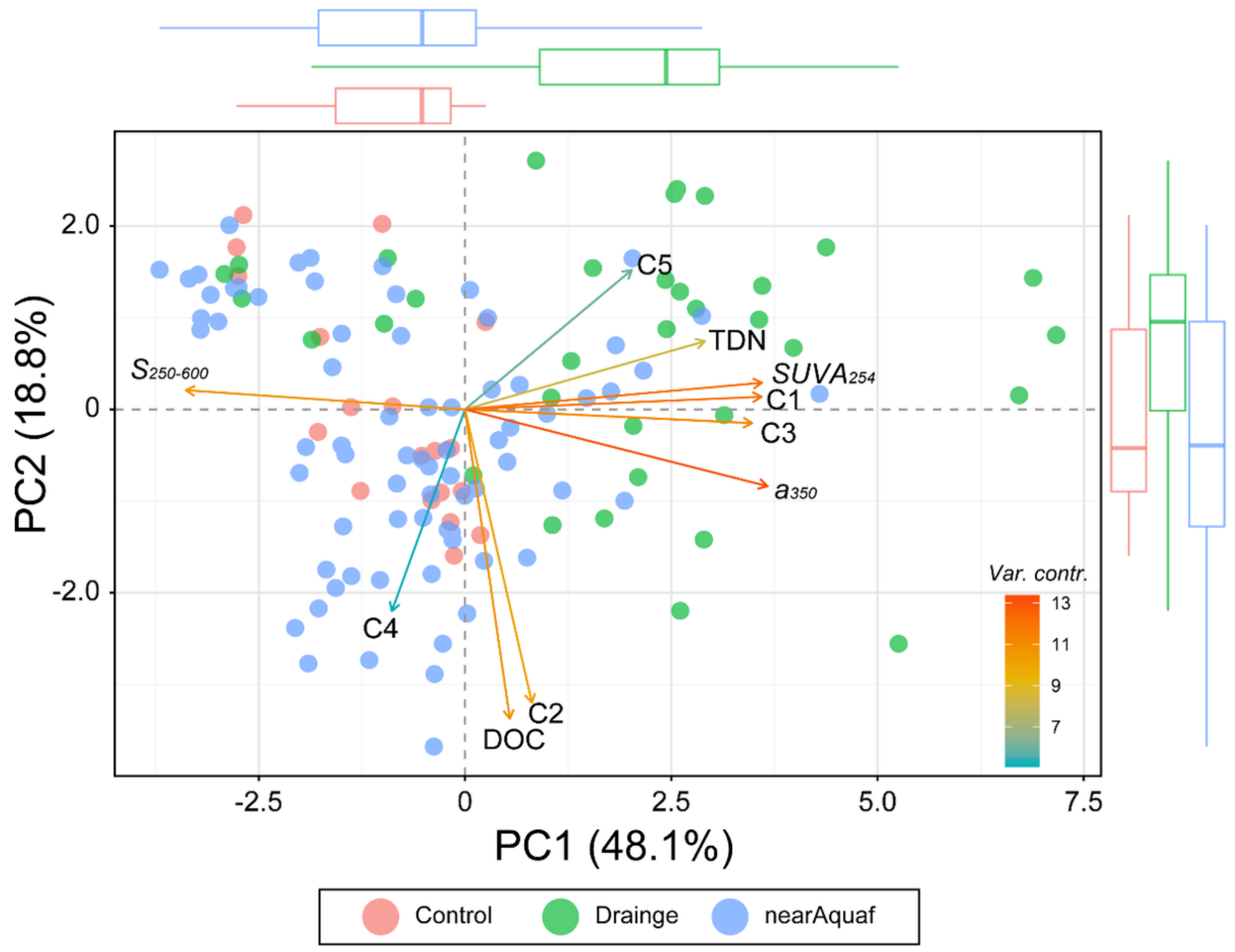

Figure 5

The principal component analysis biplot of scores and loadings for the dataset of the control site (red), the drainage (green), and near-coastal water from the aquafarm outlet (blue). Loadings for the DOM parameters (DOC, TDN, a350, S250-600, SUVA254, and the PARAFAC components) are indicated as vector arrows, and the colour of the arrows shows variable contributions to the principal axes. The boxplots at the up and right sides indicate the variation of PC1 and PC2, respectively. 


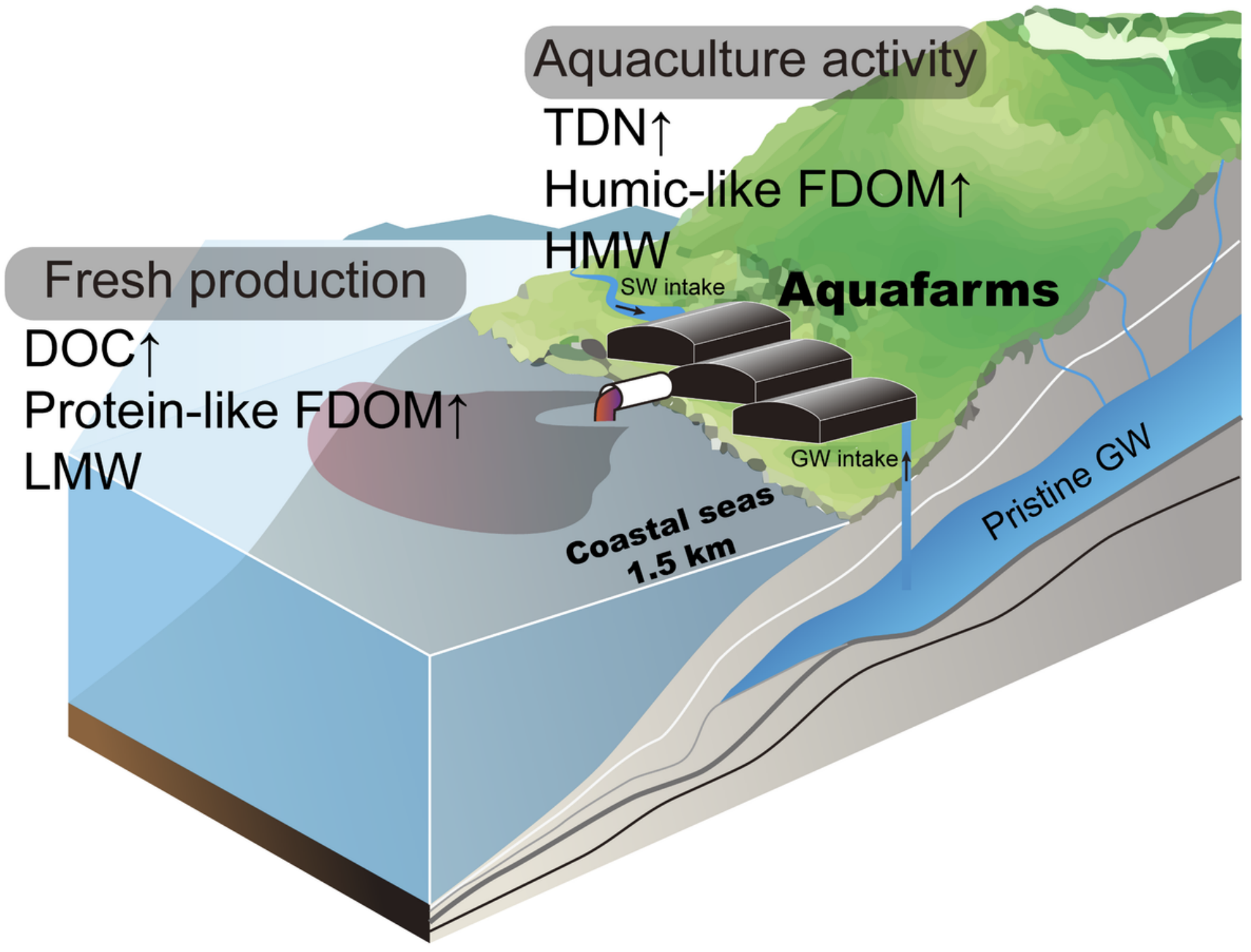

Figure 6

A schematic diagram illustrating the properties and origins of DOM near the coastal Jeju Island affected by the discharge from the aquaculture facilities.

\section{Supplementary Files}

This is a list of supplementary files associated with this preprint. Click to download.

- Sl.docx 